\title{
The Indianization of Colonial Medicine
}

\section{The Case of Psychiatry in Early-Twentieth-Century British India}

\author{
Waltraud Ernst
}

\begin{abstract}
Die Indianisierung der Kolonialmedizin: Das Beispiel der Psychiatrie im Britischen Indien in der ersten Hälfte des 20. Jahrhunderts

Anders als die weitgehend in der Geschichtsschreibung belegte psychiatrische Anstalt für Europäer und Europäerinnen mit ihrem englischen Leiter Owen Berkeley-Hill ist die weitaus größere Institution für indische Patienten und Patientinnen im nordindischen Ranchi bisher nicht untersucht worden. Im Mittelpunkt dieses Beitrags steht die Karriere des Leiters dieser Institution, Jal E. Dhunjibhoy, zu Beginn des 20. Jahrhunderts als von der britischen Kolonialregierung eine Indianisierung der medizinischen Einrichtungen angestrebt wurde. Im Gegensatz zu bisherigen Studien über intermediaries und middles konzentriert sich dieser Aufsatz auf einen hochrangigen einheimischen Mitarbeiter. Die verbreitete Annahme zwangsläufiger historischer Prozesse wird dabei differenziert, eine regionale Kontextualisierung vorgenommen und die Kontinuität offener und versteckter Diskriminierung indischer Mediziner in Bezug auf Entlohnung, gesellschaftliche Stellung, fachliche Anerkennung, posthume Würdigung und historiographischer Berücksichtigung herausgearbeitet. Es wird verdeutlicht, in welcher Weise koloniale Akteure in bestehende gesellschaftliche Disparitäten und soziopolitische Prozessen verstrickt waren und wie die Karriere eines leitenden Mediziners von einer Vielzahl von außermedizinischen Zusammenhängen bestimmt wurde. Gleichzeitig wird hervorgehoben, dass ihre strukturelle Positionierung als inbetweens, Kollaborateure oder Repräsentanten einer erfolgreichen Dekolonisierung für ein nuancierteres Verständnis ihrer beruflichen und persönlichen Identitätsformierung nicht ausreicht.
\end{abstract}

Schlüsse/wörter: Parsen, Rassismus, Identität, Nationalismus, Kolonialmedizin

Keywords: Parsi, racism, identity, nationalism, colonial medicine

The development of psychiatry in British India has been examined by historians mainly in relation to the trajectory of British colonialism. This is highly appropriate not least because even at the time medical services were considered by colonial officials to be the best justification of colonial rule. As Hubert Lyautey suggested in relation to French military medicine in Africa, "la seule excuse de la colonisation c'est le médecin." (Epigraph in MacDonald 1950) In South Asia the British colonial project began in the late eighteenth 
century-much earlier than in other regions such as Africa. Following the hegemonic premises of colonial rule, the upper ranks of the colonial medical service in India were, during most of the period, occupied by Europeans only. However, the interaction between colonizer and colonized changed considerably in the early twentieth century. Historians of colonial medicine in India have rarely explored how developments - such as the decentralization of some of the colonial services in 1919; the establishment of local self-government in the various provinces in 1935; and in particular the "Indianization" of the colonial services-affected western-trained Indian doctors and the nature of medical service provision.

These developments during the early twentieth century bring into relief a number of important issues and questions. Foremost among these is whether members of the gradually emerging group of Indians in senior positions are most appropriately pigeonholed as mere collaborators with the colonial project who fulfilled Macaulay's earlier nineteenth-century vision of the British colonial state and of its educational institutions as raising an Indian middle class that could interpret "between us and the millions whom we govern-a class of persons Indian in colour and blood, but English in tastes, in opinions, in morals, and in intellect." (Quoted in Stokes 1959: 46) The experiences of colonial subjects and mediators between the indigenous uneducated "masses" and the rulers were, in the context of French North Africa, described by Fanon in 1952 in his Black Skin, White Masks. Being a psychoanalyst by training, Fanon focused on the "psychopathology of colonization," namely the feelings of dependency and inadequacy that he considered the consequence of "black subjects" embracing the culture of the colonial motherland (Fanon 1967, also McCulloch 1995). Fanon's work developed from earlier debates on négritude, which had also grappled with the social and psychological consequences of French colonialism during the 1920s and 1930s. This is, significantly, also the main period with which this article is concerned.

The role of, and the psychological impact on, Macaulay's indigenous "mediators"-or members of what Marxist and dependency theory scholars in the 1970s and 1980s have termed the "comprador bourgeoisie" — has received considerable critical attention throughout the twentieth century among historians of colonialism and those involved in colonial liberation and postcolonial movements. More recently there has been a conceptual shift towards questions of "identity" and in particular "multiple identities" allowing for a more comprehensive and nuanced assessment of the condition of the colonized. ${ }^{2}$ In the history of colonial psychiatry, the issue of how to conceptualize the gradual incorporation of western-trained, indigenous practitioners into the senior ranks of the colonial medical service has however rarely arisen (excepting Mills 2001). This is partly due to the fact that historians of psychiatry more generally have begun only very recently to shift their focus from the nineteenth to the twentieth century, with "no narrative in sight which can 
explain the psychiatry of the 20th century, comparable to the authoritative coherence achieved for the 19th century." (Hess/Majerus 2011: 139) The development of psychiatry in British India has been written mainly in reference to nineteenth-century colonial culture. On the other hand, existing work by medical historians on the important role of "intermediaries," "middles" or "subalterns" within colonial settings has concerned itself mainly with those appointed to positions at the intermediate, subordinate or auxiliary level (Digby/Sweet 2001, Mills 2000, Lyons 1994, Khalid 2011) or with the development of medical research and science. ${ }^{3}$

This article breaks new ground both in relation to the period covered and the object of investigation. It focuses on the 1920s and 1930s, when the Indianization of the colonial medical service was in full swing and Indians increasingly came to occupy senior appointments in the Indian Medical Service and in the other medical service organizations in India. Some of the issues related to the position of indigenous agency in the field of psychiatry are explored, and the personal and professional experiences resulting from it. It should be stressed that the intention is not to provide an apologia for elitefocused historical accounts that exonerate the indigenous upper and middle classes' self-interested pursuit of social status and political or professional power. Rather, it explores how colonial subjects in senior positions in India negotiated the changing parameters of colonial rule just a couple of decades prior to Independence. Such subjects at times successfully cut across the boundaries of colonial preferentialism in some respects, while being simultaneously caught up in professional competition and subject to social prejudice rife among the different segments of European and Indian society. The evidence is derived mainly from colonial government reports, British medical journals, personal correspondence and the institutional records pertaining to the Indian Mental Hospital at Ranchi (since 1998 Ranchi Institute for NeuroPsychiatry and Allied Sciences). At the centre of analysis is the career of this institution's superintendent, J. E. Dhunjibhoy.

\section{Europeans and Indianization}

The Indian gentleman, with all self-respect to himself, should not enter into a compartment reserved for Europeans, any more than he should enter a carriage set apart for ladies. Although you may have acquired the habits and manners of the European, have the courage to show that you are not ashamed of being an Indian, and in all such cases, identify yourself with the race to which you belong. (Hardless 1920: 51)

Until 1855 no "natives" were supposed to be in senior positions in British India. Subsequently, Indians were allowed to occupy higher-level roles. However, public proclamations and official regulations did not always adequately affect 
or mirror British officials' sentiments and unofficial practices. In addition to persistent racial prejudice, medical degrees acquired at medical colleges in India were not recognized for appointments in the senior medical service until 1892. Prior to this Indians had to go to Britain to sit the qualifying exams in London. Not many did this, as travel to Europe was not only arduous and costly but also entailed crossing the sea (kala pani), which was a problem especially for higher-caste Indians concerned about caste pollution. The ratio of Indians in senior positions increased only slowly to about three percent by 1905, five percent in 1913, and about six percent in 1921 (Harrison 1994: 31-34, Jeffery 1979: 311). Those few who broke the structural glass ceiling imposed by colonialism and rose above cultural inhibitions faced severe difficulties within a racially divisive and hostile colonial society. In sum, Indianization of the medical services was a complex process, not least because the nineteenth-century legacy of structural discrimination continued to persist in unofficial practices, posing obstacles for the career development of Indians admitted to the senior medical service.

In 1925, 1,226 Indian patients were transferred from dilapidated institutions in Dacca (Dhaka), Berhampore and Patna to the brand-new Mental Hospital for Indians at Ranchi in the northeast of India. The person responsible for the patients' complicated transfer arrangements was Captain J. E. Dhunjibhoy, who had been trained at Bombay (Mumbai) Medical College, some 1,600 km away, in the west of India. He had graduated with a, by then fully recognized Bachelor of Medicine and Surgery. He was also a fellow of the College of Physicians and Surgeons, a distinction considered highly prestigious among medical practitioners. Dhunjibhoy was made a member of the Indian Medical Service, which was then the supreme medical service, being strongly linked with the British Medical Association. As was common practice at the time, the appointment was both military and civilian. No suitable vacancy being at the time available in Bombay, his services were "placed temporarily at the disposal of the Government of Bengal," across the other side of the subcontinent, where a position needed to be filled.

The new superintendent lived up to the responsibility bestowed on him in many ways. He managed to shift the patients in three sets of 212, 690 and 324 from their previous institutions at Dacca, Berhampore and Patna respectively. Some travelled by steam boat and cart, without "the slightest mishap"-escape, suicide, homicide or accident-as noted in the Ranchi Mental Hospital Reports. ${ }^{4}$ This was not easy, considering that about one fifth of the patients had a history of violence and an even larger proportion suffered from various physical illnesses and weakness, in addition to severe mental afflictions (Ernst 2010). Dhunjibhoy's achievement was acknowledged locally and in Britain: by the most senior medical officer in the province, the inspector-general of civil hospitals, Bihar and Orissa, H. Ainsworth ${ }^{5}$, and in the Journal of Mental Science. ${ }^{6}$ During his tenure at Ranchi (1925 to 1940), he also consistently achieved 
the lowest mortality rate of all institutions in India. At that period there existed 22 mental hospitals in British India, in which a total of 10,000 patients were confined. His ambition was to provide an institutional setting like the most advanced in western countries, but adapted to "Eastern conditions." (Dhunjibhoy 1930: 254) His record of managerial and medical accomplishments was indeed impressive.

Dhunjibhoy's further training and specialization was facilitated by the colonial government. This was commensurate with the Indianization of government services pursued during this period-enforced, not least, to appease increased anti-colonial strife. He was sent to Europe and North America on a number of occasions. For example, in 1930 he was chosen to "attend as India's delegate the First International Congress on Mental Hygiene" in Washington. ${ }^{7}$ On an earlier tour to Europe in 1923, his brief had been to make himself familiar with the latest scientific treatments and managerial practices in the field of psychiatry. He toured England for six months, "studying mental and nervous disorders" and visiting "many modern Mental Hospitals of England," before going on to see "several mental hospitals and clinics" on the "Continent of Europe." 8 On his return, he invariably introduced some of the procedures that were then at the cutting edge of psychiatry (Ernst 2010). He also engaged in several experimental clinical trials, publishing his findings in specialist journals, and trained students from Patna Medical College and the department of psychology and philosophy of the Universities of Calcutta and Dacca. When the mental hospital was recognized in 1936 by the Universities of London and Edinburgh for postgraduate study, he was responsible for students working for "diplomas in Psychological Medicine."

There is, however, evidence that Dhunjibhoy's lot was not an easy one and that his labour and achievements were not acknowledged by all of his European colleagues. He became the target of criticism and discrimination-not so much despite his elevation to a senior position but because of it. The new government policy of Indianization of the colonial service did not do away instantly with discriminatory practices and ingrained adverse attitudes among European practitioners. Issues of race and class, and professional competition within the context of job shortages were rife. Structural inequalities that had affected staff in earlier decades persisted, ensuring the continuation of an employment hierarchy favourable to Europeans.

\section{Structural Inequities}

The Indian Medical Service pay scales for Europeans and Indians in the early twentieth century were apparently equal, being based, as before, on formal qualification and length of service. Dhunjibhoy was paid Rs. 1,350 per month in 1925, when he started at Ranchi as a captain. On reaching, in due course, the rank of major, in 1928, he earned Rs. 1,500 (and Rs. 1,650 from 1931). This was apparently in line with what his European counterpart, Owen Berkeley-Hill, 
superintendent at the neighbouring mental hospital for Europeans and higherclass Eurasians, was paid as a major (i.e. Rs. 1,200 in 1920, Rs. 1,350 in 1921). However, Dhunjibhoy was in charge of the largest mental hospital in India (confining, on average, 1,300 patients), while his European counterpart was responsible for a much smaller number of Europeans and higher-class Eurasians (a maximum of 102 men and 96 women). ${ }^{10}$ Berkeley-Hill also had the benefit of working in an institution that provided care on a superior scale, commensurate with the higher social standing of its patients. A range of discretionary payments and special allowances were also common. It is therefore difficult to ascertain the pay differential between European and Indian staff. That there was such a differential is clear not least as Dhunjibhoy himself seems to have been acutely aware of it. One of his daughters noted: "I know my father complained from time to time about racism. He received about Rs 1000 less than his British counterparts."11

\section{The Medical Market Place and European Racial Prejudice}

Despite the remunerative inequities, Dhunjibhoy was a good advert for the Indianization of the colonial services. He had been admitted to what the British Medical Association considered to be the "superior civil medical services,"12 the Indian Medical Service. At the time, the medical market place in British India was wide-ranging, encompassing, alongside the Service, civil medical practitioners, medical missionaries, and members of the Royal Army Medical Corps. This plurality was subject to a highly hierarchical order, with Indians practicing indigenous medicine being relegated to the bottom rungs of the ladder. Indians were also subject to severe hostility on the part of European colleagues who rightly feared Indian "encroachment."

There was also the issue of whether Indianization would lead to Indians being permitted to treat Europeans and to examine them during training. As Jeffery 1979 and Chakrabarti 2009 have shown, Europeans held strong views on this and expressed them in no uncertain terms at the highest level during the 1910s and 1920s. For example, the governor of Bombay, George Lloyd, wrote to the secretary of state, Lord William Peel, in 1923: "I need scarcely add that I should never dream of allowing European patients in our hospitals out here to be used as clinical material for the study of Indian medical students." (Quoted in Chakrabarti 2009: 189) Sentiments such as these marked the context within which Dhunjibhoy received his training and had to function on a professional and personal level in a leading medical position.

Persistent racist attitudes also had an impact on professional matters, as in the case of one of Dhunjibhoy's locums, Dr. J. N. J. Pacheco, who took over at Ranchi in 1935 while Dhunjibhoy was travelling abroad. Pacheco was a European and had previously worked at the European Mental Hospital at Ranchi as a temporary replacement for Berkeley-Hill, who had retired in December 1933. In his final report on Dhunjibhoy's institution, Pacheco 
criticized one of the treatments that had customarily been applied (namely "injections of arsenical preparations and a course of malarial therapy" in neurosyphilis), arguing that it had been "shown by research workers in Europe recently to be somewhat disappointing and uncertain." ${ }^{13}$ He suggested a different kind of procedure, the Swift-Ellis method, which "consists in the injection of the patient's own serum which has been salvarsanised, into the spinal canal, so that the drug reaches the brain and its tissues directly"14failing to mention that this had also been proven efficacious only in some conditions and involved a risky procedure (Ernst 2010: 111-114). Dhunjibhoy took pains in his subsequent reports to justify his treatment methods and show that they were evidence-based and in tune with latest professional knowledge. It is difficult to judge whether Pacheco's intention had been to establish that Dhunjibhoy's standards were "still far from being those of his British brother," as the British Medical Association had suggested in 1913 in regard to "the Indian" more generally. ${ }^{15}$ It is likely though that Dhunjibhoy, brought up and working within a highly prejudiced context, would have been alert to any potential innuendo and criticism of his expertise, therefore going out of his way on this occasion to justify his clinical practices. As Memmi (1965:120) pointed out in his work Colonizer and Colonized, those working for and identifying with the colonial rulers would be aware that they were not respected regardless of how well they tried to excel in their work and fitted in with polite colonial society.

For his part, Dhunjibhoy decided not to hit back and comment on a much more tangible, tragic consequence of Pacheco's time at the institution: the fact that the mortality rate had increased considerably. It was 2.41 and 2.52 per cent in 1934 and 1936, while Dhunjibhoy was in charge, and 3.45 during Pacheco's time. ${ }^{16}$ Whatever may have caused the death of an extra five female and ten male patients that year, it is difficult not to assume the worst with regard to Pacheco's management of an institution dedicated to the care of Indians and run by an Indian, if we consider his recount in the British Medical Journal in 1961 of a highly objectionable episode of racial prejudice and cruelty that he clearly found amusing (Pacheco 1961: 459). Narrating the lucky escape into a lifeboat of a highly decorated medical officer (J. J. Harper Nelson), when the ship he was sailing on was sunk by a U-boat in the English Channel, he told the readers: "One of the ship's officers tried to push him off with an oar, thinking he was a khalasi [South-Asian manual worker or sailor, W. E.], as Nelson was black all over from oil and soot, and there was little room in the crowded boat." Harper Nelson "shouted out" and was "at last recognized and taken in". Being clearly oblivious to how the British officer's intentions towards what he presumed to be a black person might raise unsettling questions, Pacheco musedas if the survival of a European of high rank in circumstances where poor nonwhites perish at the whim of Europeans needed a transcendental rationale: "Was it coincidence, was it chance or fate, that came to his help in an 
impossible and extraordinary situation? I prefer to think it was the hand of Providence that mercifully extricated him from certain death." (Ibid.) This seems to be an astounding conclusion as it was clearly neither fate nor a god, but a British officer who decided who was to survive the ordeal. Perhaps more astounding still is the fact that the British Medical Journal could nonchalantly publish this anecdote as an amusing tribute to Harper Nelson's resilience and longevity, in 1961, 14 years after Indian Independence.

\section{The Medical Market Place and Indian Competition}

Professional competition and fears of outsider infringement on career opportunities and private medical practice also prevailed between Indians aspiring to find a foothold in the medical market place, in particular at a time when western medicine was the mode of healing preferred by central and provincial governments and indigenous practices were marginalized. Since South Asia is a large sub-continent, which was divided into separate provinces under British control (and about 600 Indian States under indigenous rulers), each region encompassed its own socio-cultural traditions and diverse communities. Dhunjibhoy's hospital catered for patients from three very different regions, namely Bengal, Bihar, and Orissa. As Bara 2005 has shown in regard to teaching and education, a certain tension existed between the Bihari and Bengali elite in the region surrounding Ranchi (then part of Bihar) because they were competing for jobs in the colonial service, with the former feeling squeezed out by the latter. Bengal and in particular Calcutta were the areas in which local elites had become westernized earlier than in other provinces, leading to Bengalis also taking up highly coveted positions in neighbouring Bihar. The appointment of an "outsider" from Bombay to one of the few existing positions involving superintendence of a medical institution could not but induce displeasure among western-trained Indian doctors from all three provinces. Potential candidates from Bihar and Orissa missed out yet again, while Bengalis were sidelined on this occasion by a contender from the major rival northern province pursuing elite westernization. Dhunjibhoy's arrival at Ranchi therefore did not constitute a particularly welcome occasion for the Indian colleagues who had to work with and under him.

Of course, Dhunjibhoy was well aware of this situation and the potential problems he might face from Indian deputies and colleagues on his transfer to Ranchi. He occasionally made a point in his reports of stressing that he was supported "so ably and loyally" by his staff_-indicating that this was something that could well have been otherwise. ${ }^{17}$ Dhunjibhoy clearly was highly diplomatic and perhaps his role as an outsider from a completely different region, across the other side of India, helped him to stay aloof from rivalries among elite groups in Eastern India. As his daughter pointed out, Dhunjibhoy and his wife led a very active social life, meeting regularly with Europeans as well as members of the local Bihari elite, thereby facilitating good relationships. ${ }^{18}$ 
At the same time, Dhunjibhoy had very good contacts in Calcutta. He frequently received visitors from there and was in touch with some eminent Bengali reformers and professionals. For example, he introduced a particular kind of dance therapy at Ranchi, the Bratachari Movement, which had been developed by the well-known Bengali civil servant G. S. Dutt in the 1930s. Dutt was renowned in Bengal for his revival of folk dance and local culture, using popular rhymes and songs in an attempt to preserve rural heritage and crafts. He was also a critic of heavy-handed British actions, such as the firing at protesters by police, and refused to deal with protesters who had participated in M. K. Gandhi's satyagraha against the Salt Act. Dutt was a Bengali nationalist. However, his Bratachari Movement appealed to Dhunjibhoy because its intention was to get together people from many different communities in India, overcoming social barriers of caste, religion, region, sex and age. This is also what Dhunjibhoy tried to achieve in his mental hospital where patients from three different provinces, different religions and social classes and castes were accommodated. His links with Dutt also made him highly acceptable to parts of the Bengali elite.

Dhunjibhoy did his best to bridge existing communal gaps, within a highly competitive professional context. He made his patients, staff and family, as his daughter remembered, "celebrate every religious feast-whether Muslim, Hindu, Christian, whatever." ${ }^{19}$ Facilities were provided for Hindu and Muslim worship, and regular services held for Protestant and Roman Catholic Christians (mainly tribals converted by Christian missionaries); water-carriers, cooks and cleaners acceptable to different caste and religious groups were employed; while interaction between different groupings was encouraged. Formally, Dhunjibhoy rose above inter-ethnic and communal strive. To what extent this also ameliorated hostility and ill-feelings on the part of potential professional competitors is difficult to gauge.

\section{Representations of Power, Professional Discrimination and Historiographic Marginalization}

The experience of social discrimination was real and tangible for senior Indian medical officers. Dhunjibhoy's daughter noted: "My father understood racism and discrimination very well." ${ }^{20}$ This had its bricks-and-mortar manifestation in the official residences provided for medical officers and is shown in Fig. 1 below of the views that present themselves to passers-by standing at the entrance gates to the European and Indian superintendents' private homes. Here, it could be argued, the persistent colonial dyad of European versus Indian became particularly discernible at the representational level.

We may well regard the kind of house a medical officer was provided with as a minor matter, related perhaps to random decisions in the public works department at the time, the idiosyncrasies or preferences of different architects, or incidental factors such as the availability of funds or construction 

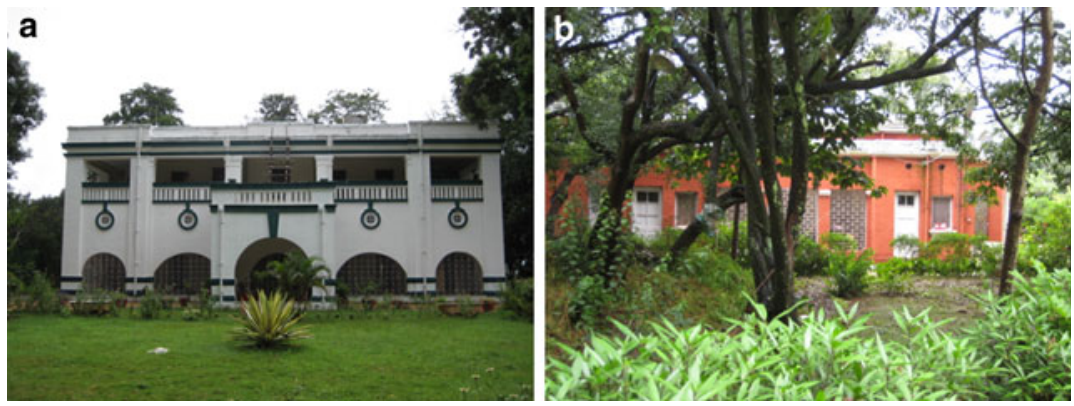

Fig. 1 Superintendents' residences: a Berkeley-Hill, European Mental Hospital b Dhunjibhoy, Indian Mental Hospital (Author's photographs 2009)

materials in different years. Some might even prefer the quaint colonial bungalow style on which Dhunjibhoy's house was modelled, nestling discreetly in a luxuriant garden setting. Dhunjibhoy's children thought of the place, locally still known as "the red house," as "a paradise."21 However, within a context such as British India, appearances did count. The European superintendent's imposing two-storey home is even nowadays suggestive of the former resident's elevated status and power, especially so in a provincial town like Ranchi, which had only recently been developed into a summer resort for those who needed a respite from the heat in a cooler, scenic area "up-country". The official representation of colonial power as manifest in the superintendents' residencies was still skewed towards European superiority.

Whether or not we are inclined to consider representational issues as appropriate indicators of social status and power, there is other evidence of discrimination against Indians in senior positions. For example, in regard to professional matters, European rather than Indian superintendents' expertise was sought by medical authorities, even in cases when the latter's experience may have been more relevant. In 1929, for example, improvements to the three mental hospitals in Madras province were planned and consultation with an expert arranged. The three superintendents were sent to Ranchi. ${ }^{22}$ Given that the majority of patients in Madras province were Indians (namely 492 out of 510, or 96 percent $)^{23}$ and that no Europeans at all were confined in two of the three institutions (at Calicut and Waltair), we might well expect that the appropriate expert to consult would have been the one person at Ranchi whose treatment of Indians was successful as no other superintendent's had been at any institution in India (including the Ranchi European Mental Hospital). However, Dhunjibhoy was not even mentioned. In the official records "going to Ranchi" meant a visit to Berkeley-Hill's institution for Europeans, where, so it was reported, "Lt. Col. Berkeley-Hill is carrying out modern methods of treatment." 24

In colloquial language, too, the phrase "going" or "being sent to Ranchi" has implicitly come to mean the former European Mental Hospital (now 
Central Institute of Psychiatry). Berkeley-Hill's institution has retained a high profile in North India-unlike its Indian counterpart (now Ranchi Institute of Neuro-Psychiatry and Allied Sciences), which declined steadily after Independence, being subject to scandals about bad conditions. Even scholars and practitioners working on Indian psychiatry have neglected the history of Dhunjibhoy's institution, some of them unaware of the fact that there were (and still are) two psychiatric facilities at Ranchi. This has become evident also during my current research. Reference to what was once India's largest mental hospital during the 1920s and 1930s was more or less absent from official correspondence between senior medical officers in the different provinces as well as from the historiography. Incorrect birth and death dates were provided in a recent article intended to pay homage to Dhunjibhoy's achievements, with the result that the man's age when he took over as superintendent in 1925 would have been 14. (Choudary 2010: 141) It seems that, just as Dhunjibhoy's bungalow was hidden behind the vegetation, whilst Berkeley-Hill's mansion was impressively conspicuous, in public lore and even in historiography the Indian Mental Hospital at Ranchi and its Indian superintendent have remained sidelined and hidden.

The enduring marginalization of the Indian Mental Hospital and Dhunjibhoy is a legacy of colonial and postcolonial developments as well as current historiographic preferences. First, Dhunjibhoy was recalled in 1940 to Bombay for war-time service in Karachi where he stayed on, becoming a citizen of the newly formed Pakistan following Partition in 1947. Apart from a few appearances at meetings and conferences, Dhunjibhoy more or less disappeared from the purview of Indian psychiatry-not least because of the development of almost completely separate traditions of medical organization and historical writing in India and Pakistan. Second, the existence of the European institution next door distracted attention from its Indian counterpart and the achievements of its Indian superintendent. Berkeley-Hill was more successful in publicizing his institution and treatment methods within a colonial context that continued to favour-albeit unofficially-European agency and its institutions. What is more, Berkeley-Hill practiced psychoanalysis on his patients. Psychoanalysis was highly fashionable during the inter-war period, attracting much attention on the part of elite European and Indian society in Calcutta. Historians too have been much more fascinated by the development of psychoanalysis in India ${ }^{25}$ than by mainstream psychiatry. The latter was at the time focused on medical treatments (such as insulin, cardiazol and malaria shock, and sedation by paraldehyde) as well as water and work or occupational therapy; all of which is far less exotic in appeal for social and cultural historians than engagement with the role of sexuality, the unconscious mind and mechanisms of repression in regard to individual, cultural and political processes.

Third, the administration of the European institution was- "fortunately," as Berkeley-Hill (1939: 252) remarked-"taken out of the hands of the 
Government of Bihar and Orissa" in the early 1920s. Mental institutions had been under provincial control since 1919, but responsibility for any Indian Medical Service staff associated with them lay with the central government. Following Berkeley-Hill's complaint and subsequent newspaper reports in The Statesman that on his arrival the European Mental Hospital was "worse than a kaffir's kraal" (ibd.: 249), the provincial authorities demanded from the central government his immediate removal. However, the European lobby in the Indian Medical Service and among the local and all-India European communities was strong and inclined to disapprove of provincial influence over the fate of a European medical officer and an institution dedicated to the care of Europeans. Berkeley-Hill had good connections with influential people, such as Colonel J. P. Murray, a member of the Indian Medical Service and the civil surgeon of Ranchi, and Miss Caroline Hubback, sister of the governor of Orissa, Sir John Austen Hubback (1936-1938). (Ibd.: 336-337) Moreover, a number of vocal interest groups such as the European Association, the European Trades Association, and the Anglo-Indian and Domiciled European Association got involved, and the European Mental Hospital was eventually removed from provincial control, ensuring funding and control by the central government. This set-up meant that Berkeley-Hill's European Mental Hospital received funding from the central government even after Independence on a much higher scale than Dhunjibhoy's institution. In the case of Ranchi, the provincialization of health services from 1919 and provincial self-government from 1935, which had been designed to empower Indian local governments, effected the decline of service provision after Independence in this particular region.

Given this wider context, it is to be expected that Berkeley-Hill would write only about the European Mental Hospital in his autobiography, All Too Human. An Unconventional Autobiography in 1939. There is but one brief reference to the central government's protracted plans to build "two large asylums, one for Indians and the other for Europeans and Anglo-Indians." (Ibd.: 242) This may perhaps be understandable, given that Berkeley-Hill was concerned with the story of his life rather than a history of the institutions at Ranchi. After all, he also referred to the other important Ranchi establishment, the large-scale government farm, only in passing, employing an ethnic stereotype when he remarked that the agricultural establishment was managed by an Irishman who, he surmised, "would probably enjoy a fight with some lunatics" while the mental hospitals were being built right next to him (ibd.: 241). However, Berkeley-Hill would have driven past India's largest and most advanced institution many times on his way to his residence and the hospital. ${ }^{26}$ Dhunjibhoy was also the only person in the whole of Bihar who was not only working in the same medical field but also lived much closer than anybody else.

Berkeley-Hill's silence is peculiar, especially since he was considered, in R. Dhunjibhoy's words, "a pariah himself" and had "incurred the displeasure" of 
friends and family by marrying an Indian woman from Cannanore in South India (Ibid.: 110). His wife, Karimbil Kunhimanny, belonged to a lower caste (Tiyyan) ${ }^{27}$ and Berkeley-Hill had been subject to social sniggering to the extent that he was (wrongly) remembered even by Dhunjibhoy's daughter to have married an "untouchable" or "sweeper woman"-an act detested by most Indians and considered as beyond the pale by Europeans in India. ${ }^{28} \mathrm{He}$ had also found signing up for the Indian Medical Service "the stupidest act in my life," coming to hate the "paralysing minor tests of conduct that are vitally important to the imagination of the authoritative dull, and in the Army the authoritative dull are in the majority." (Ibid.: 79-80) He came "within an ace of being expelled," following minor incidents such as when he was "ordered to grow a moustache" and generally rebelled against "elderly men" and the "mob of gentlemen-employees who know very little and who do even less." (Ibd.) Berkeley-Hill clearly had his own axes to grind. It is doubtful if he was able to fully empathize with his Indian colleague. Marrying an Indian woman, whom he regarded as "one of the dearest creatures I have ever known," clearly did not exempt him from disdain for Indians more generally (ibd.). When bestowing on Kunhimanny the distinction of having been "the only Indian I have ever met who can be relied on consistently to do things promptly and properly" and pointing out that she had "an infinite capacity for taking pains," he deftly combined a patriarchal compliment with a sweeping racist criticism of Indians (ibd.: 111).

What concerns us most within the context of the Indianization of the colonial service is that Berkeley-Hill was able to rebel against what he perceived as his seniors' bigotry, and, as a European, he largely got away with it. He did gain a reputation as a colourful if cantankerous eccentric-a role to which he seems to have been happy to live up to, albeit with occasional bitterness and sarcasm. Overall, it does not appear to have done him much harm in terms of his professional career. In contrast, Indians exposed to systemic prejudice and parochial narrow-mindedness had to bear them-lest they got the sack or, in the light of the wider political context of anti-British agitation, fell under Europeans' suspicion about their loyalty. The official records are full of court cases against Indians employed by the British who were dismissed and/or imprisoned when they displayed anti-British sentiments and were engaged in nationalist pro-Independence activities. Even Indian employees' children were expected to tow the line. Dhunjibhoy's daughter remembered in 2009:

The British, at the time, were also threatening higher Indian officers and functionaries, if their children joined the Freedom movement. They were warned that they would lose their pensions. My sister [celebrated Pakistani poet and professor of literature, Maki Kureishi] was actively supporting the Congress [Indian National Congress Party, active in the Independence movement] and I, at twelve, had paid my four annas to the CPI [Communist Party of India]. It was a time of tension and many arguments at home. ${ }^{29}$ 
Dhunjibhoy and Berkeley-Hill were reportedly strong characters with, what would nowadays be called, "strong egos." This might not have facilitated any close relationship. Furthermore, a strong personality and views were desirable attributes of a superior British "character," encouraged if displayed by Europeans of the higher orders supposedly attuned to the correct hierarchical circumstances within which they could find expression. Lapses by middle and upper-class Europeans who overstepped the line, venting strong feelings and views were, as Berkeley-Hill's case shows, politely ignored or mildly censored or attributed to gentlemanly eccentricity. It was however an altogether different situation if Indians (or lower-class Europeans) displayed similar traits. This is evident in the response by one of Dhunjibhoy's European superiors to a professional and, in a wider sense, socio-political matter raised in a hospital report. $^{30}$

On return from one of his overseas tours in 1932, Dhunjibhoy was full of fresh ideas and enthusiasm and proclaimed in a lengthy report on the merits of mental hygiene: "Like the Western Countries India must also launch a well organised programme of mental hygiene." ${ }^{31}$ He suggested it had a "prominent place" in a "nation-building programme," ensuring the "onward march to civilization." His argument culminated in a lengthy quote from the preamble of the American Foundation for Mental Hygiene of which he was not only a member but also on its "International Committee of 100."32 Alas, Dhunjibhoy's superior, Colonel L. Cook, inspector-general of civil hospitals, the highest authority on medical matters in the province of Bihar and Orissa, rejected Dhunjibhoy's suggestions, which included "ample facilities for the treatment of its mental and nervous breakdowns." 33 Cook emphasised the limitations imposed by financial considerations and the "alternative policy of allowing the care of the mental cases to devolve upon the communities where they reside." ${ }^{34}$ He went on to argue that, until the circumstances and extent of mental deficiency are ascertained by an "authoritative official enquiry," he considered it "premature to suggest any measures for its prevention, either by segregation, sterilization or imposing restrictions on the relatives or guardians of such cases." ${ }^{35}$ Finally, Cook crisply concluded: "Major J. E. Dhunjibhoy, IMS, continues to administer the institution with the self-confidence and acumen which characterises this officer." ${ }^{\text {"3 }}$

Clearly, while the medical services were being "Indianized," the new brand of Indian colonial servant was not to take the initiative to Indianize or reform medical policy. It is of course important to consider the wider context within which Colonel Cook would have read the suggestions on mental hygiene and Dhunjibhoy received his superior's short shrift. There were persistent financial problems and policies of self-help and decentralization were championed. Moreover, during the 1920s and early 1930s the Independence movement in its various manifestations as political agitation, non-cooperation and armed rebellion had been particularly strong throughout India. By 1933, the language 
of "nation-building" and reference to the needs and problems of different communities was particularly contentious. The Indian National Congress had been declared illegal just a year earlier and Gandhi had been arrested and imprisoned, starting his "fast unto death" against the segregated representation of different communities in the provincial legislature suggested by the British in 1932. In addition, the province in which Ranchi was located had seen decades of armed struggle over various issues related to provincial boundaries and discrimination against particular communities. Berkeley-Hill had described the situation in 1920 in his characteristically mocking way:

In 1920, owing to so-called "political unrest," those who considered themselves responsible for the maintenance of peace and goodwill in Ranchi got somewhat rattled. Measures - of sorts-were not only discussed but in part actually taken to save British lives from mob fury. (Berkeley-Hill 1939: 260)

Even the mental hospital, on account of being a British institution, was a potential target and was therefore provided with a machine gun.

Within such an anti-British context, an Indian subaltern's reference to concepts such as nation-building and civilization could only be read by an official representative of the empire such as Colonel Cook as potentially mutinous. As a medical professional, Cook might have felt the need to carefully engage with the suggestions made by a colleague before refuting them, but it was unnecessary for him to patronize Dhunjibhoy in his aside about the superintendent's personal characteristics. It would have been difficult for Dhunjibhoy not to read Cook's statement as a criticism of his character and a clear message that the initiation of new policies was not a matter that Indian medical officers were supposed to pursue.

\section{The Parsis and Indianiziation}

\section{Professional Closure and the Pathologization of a Successful Community in India}

There was another occasion around the time of the Cook episode when the wider socio-political context, European prejudice and issues of mental hygiene and eugenics caught up with Dhunjibhoy. An article published in 1928 in the British Medical Journal on seemingly narrow clinical matters led to a flurry of exchanges between its author, Lieut.-Col. W.S. Jagoe Shaw, and two readers. Shaw had been superintendent of the mental hospital near Poona (Pune), in Bombay Province, and had written on the prevalence of dementia praecox (schizophrenia) among the Parsi (Zoroastrian) community of India. The Parsis were a small community of not more than 100,000 people at the time and most of them lived in Bombay. From the "Western point of view," they were, as Shaw (1928a: 567) put it, "far more in touch with our civilization than any other 
Indian people," and incidentally had a strong ethos of philanthropy, also being engaged in the provision of mental health care facilities in Bombay. ${ }^{37}$ During his time at the mental hospital, Shaw had seen a number of Parsi patients and on the basis of his general observations (but no reliable qualitative or quantitative data) postulated that Parsis had a higher incidence of dementia praecox than Hindu and Muslim patients.

Two readers of his article were irked by the suggestion that there was consensus among researchers that schizophrenia was indeed a hereditary disease and the claim that cousin marriage among Parsis—or "inbreeding"was "a very definite cause of the disease " and that "moral imbecility," "feeblemindedness" or "mental deficiency" as well as epilepsy were also implicated (Shaw 1928a: 566, 568). Shaw had also written: "Nowadays at all events, the common Parsee [Parsi, W. E.] stock is seriously tainted with dementia praecox" and, because of Parsis' "proverbial" trait of "jealous family secretiveness," he suggested, derisively, that research ought to be "carried out by a Parsee of an unusually altruistic type." (Ibid.: 567-568) He concluded that the subject was of "immense importance sociologically and eugenically." (Ibid.: 568)

The first letter of outrage and criticism was printed just a week later. Its author, Arthur Brock (1928: 634), argued that Shaw had in fact, "inadvertently," demonstrated a "more important cause" for the high incidence of dementia praecox, namely "Western' education and civilization generally." Brock was a medical doctor with an M. D. from Edinburgh, but he was also an advocate of the emergent field of sociology. He was the author of Health and Conduct (1923) in which he argued that there were "parallels between human diseases and diseases of the body politic " and that current discontents were mainly a mental condition-a "psycho-sociological upset comparable to ,shellshock'." (Quoted in Devine 1924: 454-455) Brock had close connections with the renowned Scottish biologist, sociologist and town planner Patrick Geddes (1854-1932), who not only wrote the introduction to Brock's book, but had also been professor of civics and sociology at Bombay University (1920-1923). Geddes claimed a relationship between spatial form and social processes (or "regionalism" and "civics") and, in his role as town planner, believed that Indian cities ought not to simply imitate European ones but should find their own expression of civic pride. Brock mirrored Geddes's contention when he suggested that not inbreeding but Western education was to blame for the "breaking up of these young people's minds." Furthermore, he noted: "If we are to advise the Parsees against anything, it is rather against their too wholesale acceptance of Western civilization." (Brock 1928: 634)

Shaw was quick to respond. In a letter written the very day after Brock's views were published, he rejected the Brock-Geddes position and affirmed that "the peculiar incidence of schizophrenia among Parsees was not traceable to any faulty education or environment." (Shaw 1928b: 728) He took issue also with the sociological habit of putting quote marks around particular phrases, 
even if these were not direct quotes but referred to the gist and implicit assumptions of an opponent's argument. Brock's reference to Shaw's alleged view that, in contrast to Parsis, Hindus and Muslims were at a "lower" stage of civilization, was strongly refuted.

Shaw's most significant comment in his rejoinder focused on Brock as "a correspondent, who does not appear to have any personal knowledge of Indian conditions."(Ibid.: 728) This kind of argument had a long tradition and was put forward especially whenever interest groups in Britain questioned the continuation of British colonial rule or the ways the empire was run by their compatriots on the ground in India. Since Shaw had worked at the mental hospital near Bombay from 1912 to 1926, he had known of many challenges by outsiders of imperial and medical policies-not least by Geddes (Aspengren 2010: 112) - and also of Indian demands and political agitation for political and medical reforms, for example in relation to the provincialization of medical services in 1919. Debates had been particularly heated in Bombay during the 1910s and 1920s, as the Bombay Medical Union (the interest group of independent medical professionals, with support from the Indian National Congress) had challenged the Indian Medical Service monopoly. Shaw would have been well aware of how contentious his ideas were, especially as he had published them in the mouthpiece of the British Medical Association, which represented the members of the Indian Medical Service in Britain, and even though they were clothed in the language of clinical debate on the heredity of mental illness and popular eugenics thinking. Shaw's views could not but be read as allegations of inferiority levelled against a community that had acquired the necessary skills, expertise and social influence to compete at the highest level for medical and political positions with Europeans. Brock had put his finger on Shaw's underlying agenda and was derided by pointing to his lack of Indian experience.

The story did not finish there. Dhunjibhoy, too, contributed to the debate. His intervention could be expected to have been considered most appropriate by the editors of the British Medical Journal. After all, being an Indian, he did have the desired "personal knowledge of Indian conditions" (Shaw 1928b: 728). He was also an expert in psychiatry and, since he belonged to the superior Indian Medical Service, he was officially well qualified. What is more, he was also a Parsi, and hence belonged to the very community Shaw had speculated about and from whom he had elicited a volunteer to shine more light on the matter of alleged heredity of schizophrenia. However, despite Dhunjibhoy's merits and qualifications, the journal printed only a highly abbreviated extract in the "Letters, Notes, and Answers" section from the well-evidenced criticism that he had advanced in response to Shaw's mostly anecdotal and impressionistic account, which had been published as a full article. The British Medical Journal clearly sided with Shaw who was a long-standing subscriber and member of the British Medical Association, and decided against publication of Dhunjibhoy's full research report. 
One of the central arguments in Dhunjibhoy's brief, published extract was that the incidence of dementia praecox was high also in England, Germany, France, Italy and America- "yet none of these nations is known to practise inbreeding like the Parsees." (Dhunjibhoy 1929: 382) Dhunjibhoy was able to back this up with statistics-but the British Medical Journal did not provide these. Shaw had selected one potential causative factor, attributing it to one select group only. About the possible cause for schizophrenia Dhunjibhoy, too, could only speculate. His assumption was that it was related to "the stresses of present-day civilization and education," but he warned against undue generalizations, pointing out that this may not be "the sole cause," but may "at least have something to do with it." Secondly he quite correctly argued that the relationship between inbreeding and schizophrenia "has never been definitely established." (Ibid.). Dhunjibhoy's objections were well-grounded in the scientific evidence available at the time. He also did not fail to point out that a "greater hereditary predisposition in manic-depressive psychoses than in dementia praecox" was assumed by researchers, so that inbreeding was more likely to produce a higher incidence of the former condition-which was not the case in relation to the diagnoses given to Parsi patients. And, finally, referring to statistics from the various mental hospitals, Dhunjibhoy pointedly noted that schizophrenia was not as rare amongst other communities in India as Shaw "imagines." (Ibid.)

Shaw did not respond to the issues raised by Dhunjibhoy. Instead he published an amended version of his original British Medical Journal piece one year later in yet another renowned British journal, the Journal of Mental Science. Although Shaw provided a good literature review in the amended article, his evidence on the Parsis was still based on conjecture and highly selective observations. Again he repeated the same questions, admitting that his observations were "pure speculations" and that there were as yet no answers: "I have come across no reference to inbreeding in any of the ordinary text-books." (Shaw 1930: 511) Despite this acknowledgement he concluded: "In any case the Parsi stock is now so seriously tainted with dementia praecox that the propriety of their abandonment of the mating of cousins should be seriously considered." (Ibid.)

Dhunjibhoy's immediate rejoinder was, as his previous one, well grounded in the existing research and also backed up by statistical data. However, it was again published only in the "Notes and News" section, but this time in a full version that included data sets from Indian institutions. In his last sentence, he pointed at a core issue:

However, if Col. Shaw will satisfy me as to why the incidence of [schizophrenia] is high amongst other communities and nations who follow western education and culture but are free from ,in-breeding,' I am quite prepared to adopt his suggestion, and take up research work in order to determine the cause or causes of the alleged high incidence of [schizophrenia] amongst the Parsees. (Dhunjibhoy 1931: 297) 
Like Brock, Dhunjibhoy had identified a particular flaw of Shaw's logic, namely that a specific diagnosis shared by highly educated Indians and westerners had been attributed to an inherited defect (based on custom) in the former but not the latter. An Indian community like the Parsis that had competed successfully with Europeans, operating at the same level with them, was considered by Shaw to be tainted by virtue of persistent cultural preference, inevitably leading to hereditary decline. The publication of Shaw's views on the mental profile of the Parsi community in two of the most high-profile British expert journals pathologized the very group that had closely interacted and collaborated with the British since the late eighteenth century and become their single most successful competitor in trade and industry.

\section{The Decline of the "Good Parsi"}

The debate sparked off by Shaw's articles was part of a wider discourse on the perceived decline of the Parsi community from the 1920s onwards. Elite Parsis and their European colleagues alike were well aware of this, making it potentially more precarious for Parsis in senior positions in the colonial services to assert their authority vis-à-vis European colleagues. Unfortunately for Dhunjibhoy, his rise in the supreme medical service occurred after the zenith of Parsi success. Reasons cited for the community's earlier success have been its religiously grounded work ethic (whereby Zoroastrianism is seen in a Eurocentric way as mirroring Weber's "protestant work ethic"); close community spirit and endogamy; lack of caste barriers; production-orientated peasant-artisan background; and, "above all, their acceptability to British patrons as stable collaborators." (Guha 1984: 117) In the first decade of the twentieth century, Parsis were consistently portrayed as more Western in appearance than members of other communities ${ }^{38}$ and about one quarter spoke English (as compared to less than 1 per cent of Jains and 0.5 per cent of Hindus).

Given the common perception that the Parsis' destiny was "bound up with the British in India," and their ambition to "see themselves as like the British and as unlike other Indians," it is not surprising that the attributes ascribed to a "good Parsi" were similar to those of an English gentleman as written in the Album of Men and Woman of India in $1906 .{ }^{39}$ These included virtues such as rationality, honesty and loyalty as well as physical prowess. (Karkaria 1896, Darukhanawala 1935) However, by the 1930s Parsi decline became a mainstream trope among European and Indian communities in British India. Reiterating Shaw's impressions, S. F. Markham, for example, noted 1932 in a report to the Parsi trustees of the Sir Ratan Tata Trust that the birth rate and literacy had declined, while insanity and unemployment were on the increase. (quoted in Luhrmann 2000: 165) Guha 1984 accounts for the rise and subsequent decline of Parsi fortunes by the changing economic trajectory of industrial and finance capital following the world economic crisis of 1929. 
He suggests that the success of the Parsis as a community was linked with their entering modern trades and industries, including joint-stock trading, banking and manufacturing corporations during the late nineteenth century, following earlier engagement in the opium and cotton trade with China and shipbuilding. Changes in the development of international trade and British monopoly capitalism during and following the period of the Wall Street crash of 1929 posed considerable problems to Parsi entrepreneurs, which lead to a shift in the community's self-perception, much soul searching and the frantic and anxious identification of a variety of social, cultural and biological factors that could be considered as plausible causes for the shift in fortune.

There have been two other strands of explanations for the changed condition of the Parsis. One focuses on the role of the Parsis as "compradors" or collaborators with the cause of colonialism and the community's decline commensurate with the death throes of British power from the period following increased anti-British agitation. This fits in with Fanon's (1967: 10) contention that "for the black man there is only one destiny. And it is white." The implication is that feelings of abandonment, painful ambivalence, selfcriticism as well as unacknowledged anger ensue at the loss of the colonial father figure. The earlier mimetic mirroring of the British representation of self and identification with the colonizer become problematic once the colonizer's authority with which the colonized elite identified itself declines.

The alternative explanation focuses on racial factors and "deterioration of moral fibre" (Desai 1940: 74) or, as Guha (1984: 118) put it, issues such as "ethnic qualities" and "value systems." This line of argument contends that the Parsi rhetoric of asserting similitude to the European entailed an assertion of distance from other non-Parsi Indian communities, which was expressed in terms of racial and cultural difference from Hindus. Dhunjibhoy's daughter confirmed this, noting that, "many Parsis of his generation did not feel particularly ,Indian'... most ..., when asked: ,Where do you come from?' would answer ,I am a Parsi-from India'." 40 The trope of Parsi racial purity and cultural distinction from other Indian communities changed into a narrative of racial decline and genetic corruption from the 1920s onwards: Endogamy or "inbreeding" was now seen to have led to degeneration of the racial stock, inducing a reduced entrepreneurial spirit, alongside reliance on easily accessible communal charity, reduced fertility and madness. According to Bulsara (1935: 33), this resulted in "the alarming problem of growing economic misery and the physical, intellectual and spiritual impoverishment of an increasing section of the community." It is within this kind of debate which ascribed social and political changes to biological factors that Shaw's publication on the alleged higher incidence of mental illness among Parsis must be set.

Both the comprador and the racial decay thesis mooted from the 1920s onwards, are highly problematic and, judging from his responses to Shaw's articles, Dhunjibhoy for one was uncomfortable with both of them (although 
he contended that inbreeding was "undesirable" (Dhunjibhoy 1931: 296)). Of course, the assumption of degenerated racial stock as a result of "inbreeding" was common during the heyday of mental hygiene and eugenics. Intriguingly, endogamy was encouraged when allegedly superior racial purity was considered the aim, as in Nazi Germany in regard to the "Aryan race," but was considered to have engendered corrupted stock in regard to particular communities that were discriminated and persecuted, such as the Jews. In a similar vein, it is, as Luhrmann (1996: 170) points out, "a weird and telling argument, in India, where endogamy is taken for granted, that in Parsi endogamy the blood of the community should be said to fold in upon itself and implode." The reason for Parsis' self perception from the early twentieth century onwards as a community subject to "decadence and degeneration" (Wadia 1949: 138) and "decline in numbers" and "decline in quality also," (Desai 1948: 74) which was repeated and reinforced by the British in India (for example, by Shaw), requires further research.

\section{Collaborators, Competitors and Ambivalence}

I think [my father] died a disappointed man, who did not understand the world around him, any more. I remember when he retired and took off his uniform for the last time-it was like an actor taking off his make up. Everything changed: his accent, his clothes, his hobbies. He slipped comfortably into becoming an old, orthodox Parsi. ${ }^{41}$

The Parsi community's mirroring of the rise and subsequent fall of the British led commentators at the time as well as postcolonial writers to consider Parsis as "compradors" or collaborators with the cause of empire whose downfall was inevitable once British rule was being challenged and brought to an end. As in Dhunjibhoy's case, many elite Parsis were indeed beneficiaries of British rule. However, those who made a career in the colonial services in the wake of Indianization during the 1920s and 1930s were both "collaborators" with the ongoing albeit fading cause of empire and allies of those Indians who pressed for the replacement of British with Indian agency in preparation for Independence. On account of this double role they were subject to divided loyalties and to mistrust as well as celebration from both sides-British and Indian.

Authors such as Memmi and Fanon, whose experience of colonialism related to French North Africa, focused mainly on the psychological cost of identification and collaboration with the aggressor: self-loathing and selfcriticism as well as loss of identity. As Memmi (1965: 140) put it: "So goes the drama of the man who is a product and victim of colonialism. He almost never succeeds in corresponding with himself." There are traces of this aspect in Dhunjibhoy's experience as narrated by his daughter. The pessimistic comprador or collaborator trope also partly explains the earlier self-confidence and later self-criticism of the Parsis as a community and Dhunjibhoy's experiences 
of continued professional marginalization on the part of British colleagues even while Indianization was progressing rapidly. The varied hurdles that were put in his way when he attempted to initiate new procedures or recommend a change in health policies attest to the continued inferiorization of senior Indians despite their elevated roles in the colonial service. However, an emphasis on Indianization as a mere ploy of colonialism and as an inherently doomed attempt at a "march through the institutions" by those involved in it is problematically narrow, as is the assumption that a "loss of self" is always inevitable and terminal. In regard to the latter, as the above quote attests, Dhunjibhoy may have been "a disappointed man," but he also (re?)-gained a former identity and inner world into which he "slipped comfortably." ${ }^{42}$

The role of those who profited from colonial rule and Indianization could of course not but be full of conflict, contradictions and "ambivalence." Looking at the structural consequences of Indian actors' ambivalent position, Nandy (1983: 14) emphasized the potential for subversion inherent in it, as he sees the colonized subject not just as "simple-hearted victims of colonialism" but also as "participants in a moral and cognitive venture against oppression." Most importantly: "They make choices." As Homi Bhabha (1994: 86) explained: "ambivalence" is inherent in colonial discourse and in the attempt by the colonized to copy the colonizer. "Mimicry" is therefore "at once resemblance and menace." R. Dhunjibhoy, too, noted that the experience of divided loyalties, or ambivalence, affected individuals deeply, creating heartache for them, but still offering the opportunity to eventually settle, even comfortably in her father's case, into a life world of their choice.

Dhunjibhoy's career can be seen as a showcase of successful Indianization of the medical services. From a moderate Indian nationalist point of view, Dhunjibhoy belonged to a group of Indians trained to take over from the British on their imminent departure from South Asia; from the perspective of radical nationalists, he was collaborating with the enemy. For the British he was an excellent representative, in particular at international events, of the British promise to entrust an increasingly larger number of Indians with highprofile positions in the move towards de-colonization. Dhunjibhoy was clearly grateful to the colonial government. Coming from a lower Parsi background, he reportedly felt "that he owed everything he had achieved to the Army and the British." ${ }^{\text {"3 }}$ This does not imply that he had any anti-nationalist inclinations or was in political allegiance with the British. His daughter described him as "not political" and, despite having met Gandhi and receiving visitors who were protagonists of the Independence movement, such as the president of the Indian National Congress, Dr. Rajendra Prasad, ${ }^{44}$ he "was not particularly nationalistic." 45 Like other Parsis, he sat on the fence of pre-Independence politics and upheaval.

Dhunjibhoy followed a tactical line of non-committal that may be read, in a negative vein, as evidence of collaborators' bourgeois self-interest or, perhaps 
more pragmatically, as an attempt at self-preservation and an endeavour to assure one's family's prosperity during a time of political turmoil. Unlike their children's generation, which, according to Dhunjibhoy's daughter "was the first generation of Parsis that identified completely with India," many of those who lived as adults through the 1920s and 1930s did not have a strong affiliation with the politics of Indian nationalism and separatism (neither Hindu nor Muslim), as they felt Parsi first and Indian second. ${ }^{46}$ Consequently, Dhunjibhoy would stay on in cosmopolitan Karachi, which became part of Pakistan after Independence and Indian Partition in 1947-although, "like many Parsis," he "disliked Muslims"-because there was "a good Parsi community and [he had] friends and [knew] no one, any more, in Bombay." ${ }^{47}$ Despite the "torn self" and "white masks" that have been ascribed to the "black skin" in colonial contexts, it seems that for Dhunjibhoy Parsiness continued to remain the essential reference point.

What is more, Dhunjibhoy was not an anglicized Indian but a cosmopolitan-albeit "orthodox"-Parsi, familiar with the life and customs of people in Britain as well as in other European and North American countries. His wife, Shirin Vacha, was also a Parsi but had been "born and brought up in Germany," in the vibrant and cosmopolitan atmosphere of pre-World War I Berlin. ${ }^{48} \mathrm{Her}$ four brothers and sisters, too, "were brought up completely European and the only son in the family never saw India," except once, for a few weeks, when he was sent as a child to Bombay-significantly, to confirm his Parsiness and "have his Navjote ceremony." 49 As Shirin Vacha had spent her early life in Europe, she "did not really regard herself as Indian." This would no doubt have shaped Dhunjibhoy's own cultural identification also. When Dhunjibhoy had to leave Ranchi (a social backwater, where according to Berkeley-Hill (1939: 242) the hospital was located at a "dismal spot" surrounded by "wilderness,") to be posted to the vibrant metropolis of Karachi during the Second World War, his wife was "glad to get back to ,civilization"." British nor Indian, but the kind of imaginary cosmopolitan place inhabited by an elite versed in the social ways and customs exhibited by the privileged of all ethnic and religious stripes in many of the large cities around the world.

\section{Beyond Colonial Medicine and Indianization}

The case of Indianization discussed above highlights issues relevant to the history of British colonialism in South Asia and the history of medicine during the early twentieth century. It has been shown that Dhunjibhoy's professional career and personal life choices reflected the new opportunities opened up during this period by the colonial government in response to nationalist demands for Indian self-government. Dhunjibhoy's experiences during his posting in a region characterized by economically-based communal tension as 
well as strong anti-British sentiments point to the importance of local factors in which senior officers were embroiled. The persistence of European racial prejudice, and resistance on the part of senior European medical staff and British professional associations to abdicating their privileged position in the medical market place show that Indianization was an officially decreed policy aimed at the abolition of British predominance and professional monopoly that did not necessarily do away with ingrained colonial attitudes among colonial servants and continued attempts at the "institutionalization of medical dependency" (Jeffery 1979). It also exacerbated competition among Indian doctors for key positions in the customarily supreme Indian Medical Service. Despite formal equity, there was continued discrimination. How the latter manifested itself and stamped the experience of senior Indian staff depended on the medical qualifications they had gained, their specific service affiliation, and local parameters. All of these factors require attention, not least in order to avoid a medical history that focuses on official policies and homogenizing proclamations rather than the continuities (as well as changes) and the multifaceted experiences and contradictory trends concomitant on the "constitution of a new imperial order" (Sinha 2001: 510) in varied localities during the period of Indianization.

The wider administrative framework within which Dhunjibhoy pursued his career was characterized by the provincialization of the medical services from 1919 and the move towards provincial self-government from 1935 onwards. European doctors resented these measures as they entailed loss of centralized power and the eventual Indianization of command structures. They also enhanced existing differences between the various regions in South Asia. These are further important aspects that any history of medicine during this period needs to take into account. Provincialization and local self government imply different trajectories in the development of "colonial medicine" and of Indianization, which requires historians to situate them within their diverse regional contexts. The common nonchalance with which medical developments in particular states, such as Bengal and Bombay for example, have been taken by historians of medicine as representative of other areas in India, requires even more probing for the twentieth century than for the colonial state in the nineteenth century. Moreover, the strength of the nationalist movement varied from region to region, involving different political and communal alliances and agenda that had an impact on how those contributing to the Indianization of the colonial services fared in the post they had been appointed to. Dhunjibhoy certainly worked within a highly politicized area, given Ranchi's proximity to Calcutta and its persistent history of local turmoil. Furthermore, the different exigencies of staffing in varied locations also affected the extent to which Indian doctors were able to moot new medical initiatives. Dhunjibhoy was unlucky to be faced with the opposition of his region's superior medical officer, Colonel Cook, who could spare no 
sympathies for any "nation-building programme" at a time when officials like him experienced acute nationalist pressure in Calcutta.

Issues of collaboration with the enemy, identification with the aggressor, loss of self, ambivalence and the success or failure of subversion of the power that be via the "march through the institutions" have been important conceptual parameters in histories of colonialism. These can certainly be traced in Dhunjibhoy's case, but they also unduly restrict the framework of analysis. As Arnold/Sarkar (2002: 57) pointed out in relation to one aspect that has preoccupied historians, namely the importance of nationalist endeavours: "Need we assume automatically that the colonized have always been primarily concerned with questions of cultural nationalism?" In Dhunjibhoy's case, his career and personal life were crucially marked by the professional advantages of Indianization and also by the problems it caused for him in his professional life with his colleagues. However, there were many other issues that affected him, such as his overseas experience and strong familiarity with European ways of life, as well as his continued primary identification as a Parsi rather than an Indian. The social and cultural backgrounds of Indian medical doctors and how their professional and personal histories and networks connect with others located outside the narrow rim of British colonialism and Indian nationalist politics are important aspects that require attention in any history of the Indianization of colonial medicine.

\section{Acknowledgements}

Many thanks are due to Dr. Akihito Haschimoto of Aichi Prefectural University Japan for letting me have a copy of Berkeley-Hill's diary; Dr. Alok Sarin, New Delhi, for allowing me to refer to his correspondence with Roshan Dhunjibhoy; Professor S. Haque Nizamie and Professor Amool Ranjan at Central Institute of Psychiatry and Ranchi Institute for Neuro-Psychiatry and Allied Sciences respectively for providing hospitality and access to their institutions during my research visit to Ranchi in 2009; and Dr. Subhash Gupta of Peninsula Medical School Exeter for putting me in touch with his former colleagues at Ranchi. I also benefitted from help with references given by Dr. Melanie Reynolds of Oxford Brookes University, Dr. Projit Mukharji of the University of Pennsylvania and Dr. Saurabh Mishra of Oxford University.

\section{Endnotes}

1 Comprador: a Portuguese term, originally employed in relation to household servants in East Asia. Used also to denote indigenous employees of trading companies-in more recent debates also outside East Asia. Concept used by Baran 1957 in relation to managers, meritocracy and technocracy. 
2 See for overview and critique Cooper 2005 and Bhambra 2009.

3 Arnold 1994, Chakrabarti 2009, Guay 1986, Harrison 1994, Kumar 1991, Raina/Habib 2004.

4 Ranchi Mental Hospital Report 1925: 9-10 (in short Ranchi Report). The Reports are held at the India Office Library and Records, British Library, London.

5 "I think Captain Dhunjibhoy and his staff deserve much credit for the success which has attended the opening of the hospital." Inspector-General of Civil Hospitals, Bihar and Orissa, to Secretary to the Government of Bihar and Orissa, Local Self-Government Department, Ranchi Report 1925: 1.

6 "The organization necessary to safely effect the transport of such large numbers can be better imagined when it is stated that the distance, for instance, from Dacca is some 300 miles, and involves a journey of 51 hours by steamer and rail and road. [...] Great credit is due to Capt. Dhunjibhoy and those who assisted him, in that the transport of this large number of patients was carried out without hitch or mishap." Journal of Mental Science reported in July 1927, 73: 485.

Ranchi Report 1930: 20.

8 Ibid.

9 Ranchi Report 1936: 23.

10 British Medical Journal 1930: 87.

11 Roshan Dhunjibhoy to Dr. Alok Sarin, personal correspondence, 20 September 2009. Many thanks are due to Dr Sarin for kindly letting me have his correspondence with Roshan Dhunjibhoy. Roshan Dhunjibhoy, a political activist, feminist, eminent documentary filmmaker and journalist, and former director of the Heinrich Boell Foundation, Germany, who had gained much insight into the politics of international development, added her critical observation: "There was a double standard of payment, in those days, one for the British and the other for the locals. Many foreign NGOs to-day, continue this racist practice." On the "grand old dame" of the Heinrich Böll Foundation, see the obituary statement on http://www.boell.de/worldwide/asia/asia-obituary-roshan-dhunji bhoy-11843.html accessed 13th June 2011.

12 Proceedings of Council (1925) Supplement to the British Medical Journal March 7th: 90.

13 Ranchi Report 1933-1935: 12-13.

14 Ibid.: 13.

15 Proceedings of Council (1925) Supplement to the British Medical Journal March 7th: 90.

16 Ranchi Report 1936: 4.

17 Ibd. 1930: 17.

18 R. Dhunjibhoy 2009 see endnote 11.

19 Ibid.

20 Ibid.

21 Ibid.

22 Madras Mental Hospital Report 1928: 5 (in short Madras Report). The Reports are held at the India Office Library and Records, British Library, London.

23 Madras Report 1929: Appendix.

24 Ibid.

25 Basu 1999, Harding 2009, Hartnack 2001, Kapila 2007, Kakar 1997, Mehta 1997, Nandy 1995, Vaidyanathan/Kripal 2003, Ramana 1964.

26 In fact the road cuts through the Indian hospital, with the male compound on one side and the female on the other.

27 Tiyyan is a caste name referring to one of Kerala's lower castes. Tiyyas were traditionally associated with toddy-tapping. In order to be able to marry, Kunhimanny joined the Brahmo Samaj.

28 R. Dhunjibhoy 2009 see endnote 11 and Berkeley-Hill 1939: 110.

29 R. Dhunjibhoy 2009 see endnote 11.

30 Ranchi Report 1930-1932.

31 Ibid.: 12.

32 Ibid. 1937: 28.

33 Ranchi Report 1930-1932: 12.

34 Cook 1933 in Ibid.: iii.

35 Ibid.: v. 
36 Ibid.

37 There was the Sir Cowasjii Mental Hospital and a dedicated Parsi ward at the Yeravda Mental Hospital.

38 See, for example, Album of Men and Women of India 1906: 62 (quoted in Luhrmann 2000).

39 Ibid.

40 R. Dhunjibhoy 2009 see endnote 11.

41 Ibid.

42 Ibid.

43 Ibid.

44 Ranchi Report 1939: 20.

45 R. Dhunjibhoy 2009 see endnote 11.

46 Ibid.

47 Ibid.

48 Ibid.

49 Ibid.

50 Ibid.

\section{References}

Arnold, David, 1994. Colonial Medicine in Transition. South Asia Research, 14, 10-35.

Arnold, David/Sarkar, Sumit, 2002. Homoeopathy in Nineteenth-century Bengal. In: Waltraud Ernst ed., Plural Medicine, Tradition and Modernity, 1800-2000. London/New York: Routledge, 40-57.

Aspengren, Henrik C., 2010. Sociological Knowledge and Colonial Power in Bombay around the First World War. British Journal for the History of Science, 43, 1-16.

Bara, Joseph, 2005. Tribal and Colonial Perspectives on Education in Chhotanagpur, 1834-c. 1850. History of Education, 34, 617-37.

Baran, Paul A., 1957. Political Economy of Growth. New York: Monthly Review Press.

Basu, Amit R., 1999. The Coming of Psychoanalysis in Colonial India. Centre for Studies in Social Sciences Enreca Occasional Paper Series, 5, 36-54.

Bulsara, Jal F., 1935. Parsi Charity Relief and Community Amelioration. Bombay: Bulsara.

Bhambra, Gurminder K., 2009. Rethinking Modernity. Basingstoke: Palgrave Macmillan.

Berkeley-Hill, Owen, 1939. All Too Human. An Unconventional Autobiography. London: Peter Davies.

Bhabha, Homi, 1994. The Location of Culture. London/New York: Routledge.

Bhattacharya, Sanjoy/Harrison, Mark/Worboys, Michael, 2005. Fractured States. Smallpox, Public Health and Vaccination Policy in British India, 1800-1947. New Delhi: Orient Longman.

Brock, Arthur J., 1928. Correspondence. Dementia Praecox in Parsees. British Medical Journal, October 6th, 634-635.

Chakrabarti, Pratik, 2009. "Signs of the Times". Medicine and Nationhood in British India. OSIRIS, $24,188-211$.

Choudary, S., 2010. Lt Colonel Jal E. Dhunjibhoy (1911-1980). Indian Journal of Psychiatry, 52, $141-142$.

Cooper, Frederick, 2005. Colonialism in Question. Theory, Knowledge, History. Berkeley: University of California Press.

Darukhanawala, Hormusji D., 1935. Parsis and Sports. Bombay: Darukhanawala.

Desai, Sapur F., 1940. A Community at the Crossroad. Bombay: New Book Publishers.

Devine, Henry, 1924. Review. Journal of Mental Science, 70, 453-454.

Dhunjibhoy, Jal E., 1929. The Heredity of Dementia Praecox. British Medical Journal, February 23rd, 382.

Dhunjibhoy, Jal E., 1930. A Brief Resume of the Types of Insanity Commonly Met with in India, with a Full Descriptions of ,Indian Hemp Insanity' Peculiar to the Country. Journal of Mental Science, 76, 254-264. 
Dhunjibhoy, Jal E., 1931. To the Editors of the ,Journal of Mental Science.' Journal of Mental Science, January, 294-297.

Digby, Anne/Sweet, Helen, 2001. Nurses as Culture Brokers in Twentieth-Century South Africa. In: Waltraud Ernst, ed., Plural Medicine, Tradition and Modernity, 1800-2000. London/New York: Routledge, 113-129.

Ernst, Waltraud, 2010. Practising ,Colonial' or ,Modern' Psychiatry in British India? Treatments at the Indian Mental Hospital at Ranchi, 1925-1940. In: Waltraud Ernst and Thomas Müller, eds., Transnational Psychiatries, Newcastle: Cambridge Scholars, 80-115.

Fanon, Frantz, 1967. Black Skin. White Masks. New York: Grove.

Guay, Yves, 1986. Emergence of Basic Research on the Periphery. Scientometric, 10, 77-94.

Guha, Amalendu, 1984. More about the Parsi Seths. Their Roots, Entrepreneurship and Comprador Role, 1650-1918. Economic and Political Weekly, 19, 117-131.

Harding, Chris, 2009. The Freud Franchise. In: Robert Clarke, ed., Celebrity and Colonialism. Fame, Power and Representation in Colonial and Postcolonial Cultures. Newcastle: Cambridge Scholars Press, 73-87.

Hardless, Harold, 1920. The Indian Gentleman's Guide to English Etiquette, Conversation and Correspondence. 2nd edition. Chunar: Sanctuary Press.

Harrison, Mark, 1994. Public Health in British India. Anglo-Indian Preventive Medicine 1859-1914. Cambridge: Cambridge University Press.

Hartnack, Christiane, 2001. Psychoanalysis in Colonial India. Oxford: Oxford University Press.

Hess, Volker/Majerus, Benoit Majerus, 2011. Writing the History of Psychiatry in the 20th Century. History of Psychiatry, 22, 139-45.

Khalid, Amna, 2011. Indigenous Staff, the Colonial State and Public Health. In: Biswamoy Pati and Mark Harrison, eds., The Social History of Health and Medicine in Colonial India. Delhi: Primus Books, 45-73.

Jeffery, Roger, 1979. The Institutionalization of Medical Dependency, 1918-1939. Modern Asian Studies, 13, 301-326.

Kakar, Sudhir, 1997. Culture and Psyche. Selected Essays. New York: Psyche Press.

Kapila, Shruti, 2007. Freud and His Indian Friends. In: Sloan Mahone and Megan Vaughan, eds., Psychiatry and Empire. Basingstoke: Palgrave Macmillan, 124-152.

Karkaria, Rustomji P., 1896. India: Forty Years of Progress and Reform. London: Henry Frowde.

Kotwal, N. B. R., 1937. A Discourse! The Naked Truth! etc. Bombay: Kotwal.

Kumar, Deepak, ed., 1991. Science and Empire. Essays in Indian Context, 1700-1947. Delhi: Anamika Prakashan.

Luhrmann, Tanya M., 1996. The Good Parsi. The Fate of a Colonial Elite in a Postcolonial Society. Cambridge, MA: Harvard University Press.

Luhrmann, Tanya M., 2000. The Traumatized Social Self. In: Antonius C. G. M. Robben and Marcelo M. Suarez-Orozco, eds., Cultures under Siege. Collective Violence and Trauma. Cambridge: Cambridge University Press, 158-193.

Lyons, Maryinez, 1994. African Auxiliaries in Colonial Belgian Congo and Uganda. In: Dagmar Engels and Shula Marks eds., Contesting Colonial Hegemony. London: German Historical Institute, 202-223.

MacDonald, Donald, 1950. Surgeons Twoe and a Barber. Being Some Account of the Life and Work of the Indian Medical Service, 1600-1947. London: Heinemann.

McCulloch, Jock, 1995. Colonial Psychiatry and "the African Mind". Cambridge: Cambridge University Press.

Mehta, Purnima, 1997. The Import and Export of Psychoanalysis: India. Journal of American Academy of Psychoanalysis, 25, 455-471.

Memmi, Albert, 1965. The Colonizer and the Colonized. Boston: Beacon.

Mills, Jim H., 2000. Madness, Cannabis and Colonialism. The "Native Only" Lunatic Asylums of British India, 1857-1900. London: Macmillan Press.

Mills, Jim H., 2001. The History of Modern Psychiatry in India, 1858-1947. History of Psychiatry, 12, 431-458.

Nandy, Ashis, 1983. The Intimate Enemy. Loss and Recovery of Self Under Colonialism. Delhi: Oxford University Press.

Nandy, Ashis, 1995. The Savage Freud and Other Essays on Possible and Retrievable Selves. Princeton, NJ: Princeton University Press.

Pacheco, J. N. J., 1961. Obituary, British Medical Journal, August 12th, 459. 
Raina, Dhruv/Habib, S. Irfan, eds., 2004. Domesticating Modern Science. New Delhi: Tulika Books.

Ramana, C. V., 1964. On the Early History and Development of Psychoanalysis in India. Journal of the American Psychoanalytical Association, 12, 110-134.

Shaw, W. S. Jagoe, 1928a. The Heredity of Dementia Praecox, British Medical Journal, September 29th, 566-568.

Shaw, W. S. Jagoe, 1928b. Dementia Praecox in Parsees. British Medical Journal, October 20th, 728.

Shaw, W. S. Jagoe, 1930. Some Observations on the Aetiology of Dementia Praecox. Journal of Mental Science, 76, 505-11.

Sinha, Mrinalini, 2001. Britishness, Clubbability, and the Colonial Public Sphere. Journal of British Studies, 40, 489-521.

Stokes, Erik, 1959. The English Utilitarians and India. Oxford: Clarendon Press.

Vaidyanathan, T. G./Kripal, Jeffrey J., eds., 2003. Vishnu on Freud's Desk. A Reader in Psychoanalysis and Hinduism. New Delhi: Oxford University Press India.

Wadia, Pestonji A., 1949. Parsis Ere the Shadows Thicken. Bombay: Wadia Press.

Waltraud Ernst

Department of History, Philosophy and Religion

Oxford Brookes University

Gipsy Lane

Oxford OX3 OBP

UK

E-mail: wernst@brookes.ac.uk 